\title{
A comparative study of the excretion of Fujiwara reaction-positive substances in urine of humans and rodents given trichloro- or tetrachloro-derivatives of ethane and ethylene
}

\author{
MASAYUKI IKEDA and HATSUE OHTSUJI \\ Department of Public Health, Kyoto University Faculty of Medicine, Kyoto, Japan
}

\begin{abstract}
Ikeda, M., and Ohtsuji, H. (1972). Brit. J. industr. Med., 29, 99-104. A comparative study on the excretion of Fujiwara reaction-positive substances in urine of humans and rodents given trichloro- or tetrachloro-derivatives of ethane and ethylene. 1,1,1-Trichloroethane, 1,1,2trichloroethane, 1,1,1,2-tetrachloroethane, 1,1,2,2-tetrachloroethane, trichloroethylene, and tetrachloroethylene were administered to rats and mice as vapours at 200 p.p.m. for 8 hours and urine was collected for $\mathbf{4 8}$ hours. The urine was analysed by the Fujiwara reaction for total trichlorocompounds (TTC), trichloroacetic acid (TCA), and trichloroethanol (TCE). All compounds except 1,1,2-trichloroethane yielded substantial TCA and TCE but 1,1,1,2tetrachloroethane and trichloroethylene much more than the rest. The results obtained during two periods of 48 hours after intraperitoneal injection were similar. The variations in the amounts of metabolites are shown to be consistent with the vapour pressures of the solvents (compounds with high vapour pressures are lost from the lungs before being metabolized) and with their known chemical properties, according to which 1,1,1-trichlorocompounds should yield TCE and TCA readily, whereas 1,1,2-chlorocompounds should not.

Excretion of metabolites from men exposed intermittently to vapours of tetrachloroethylene and trichloroethylene were also studied. Both gave enough TCE and TCA, but trichloroethylene gave considerably more, in accordance with its relative instability to oxidation.
\end{abstract}

In recent years increasing attention has been paid to the evaluation of urinary metabolites as a measure of exposure to organic solvents. The Fujiwara reaction enjoys a wide reputation as a method of analysis of urine for trichloroethylene metabolites (Browning, 1965a), but investigation of possible applications to the analysis of the metabolites of other chlorinated solvents is rather limited.

In the present study urine of humans and rodents exposed to several chlorinated hydrocarbons was analysed with a modification (Tanaka and Ikeda,
1968) of the Fujiwara reaction and the results are discussed in relation to the metabolism and alveolar excretion of the solvents.

\section{Materials and methods}

Animals

Wistar rats (about $70 \mathrm{~g}$ ) of both sexes and female DD mice (about $25 \mathrm{~g}$ ) were used. Preliminary experiments revealed no differences in metabolism between the two sexes under the conditions studied. They were fed on commercial laboratory chow and water ad libitum. 
Chemicals

1,1,1,2-Tetrachloroethane was obtained from Aldrich Chemical Co., Milwaukee, Wisconsin, U.S.A., while other sources were local. The solvents and their physical properties are listed in Table 1.

\section{Analysis of urine}

The urine from each group of animals (5 to 6 rats or 10 mice per group) was collected separately from faeces and pooled. Metabolites were determined colorimetrically by the Fujiwara reaction under the conditions described previously (Tanaka and Ikeda, 1968). The optical extinction obtained after oxidation of the urine sample was attributed to total trichlorocompounds (TTC), that without oxidation to trichloroacetic acid (TCA), and the difference between the two to trichloroethanol (TCE). The spectral patterns of the urinary metabolites after the Fujiwara reaction were the same for all the solvents studied.
Vapour concentrations

The concentrations of trichloroethylene in an exposure chamber were determined with Kitagawa detection tubes (Kitagawa, 1960). For other solvents, equimolar amounts were introduced into the chamber.

\section{Results}

Urinary metabolites

After exposure Groups of rats were exposed to the vapour of the solvents listed in Table 1 at a concentration of 200 p.p.m. for 8 hours. Urine was collected for 48 hours from the beginning of exposure. The results of analyses of urine are summarized in Table 2. Exposure to trichloroethylene led to excretion of both TCA and TCE, as reported in various papers (for a review, see Browning, 1965a). Both

TABLE 1

Chemical and Physical Properties of the Solvents

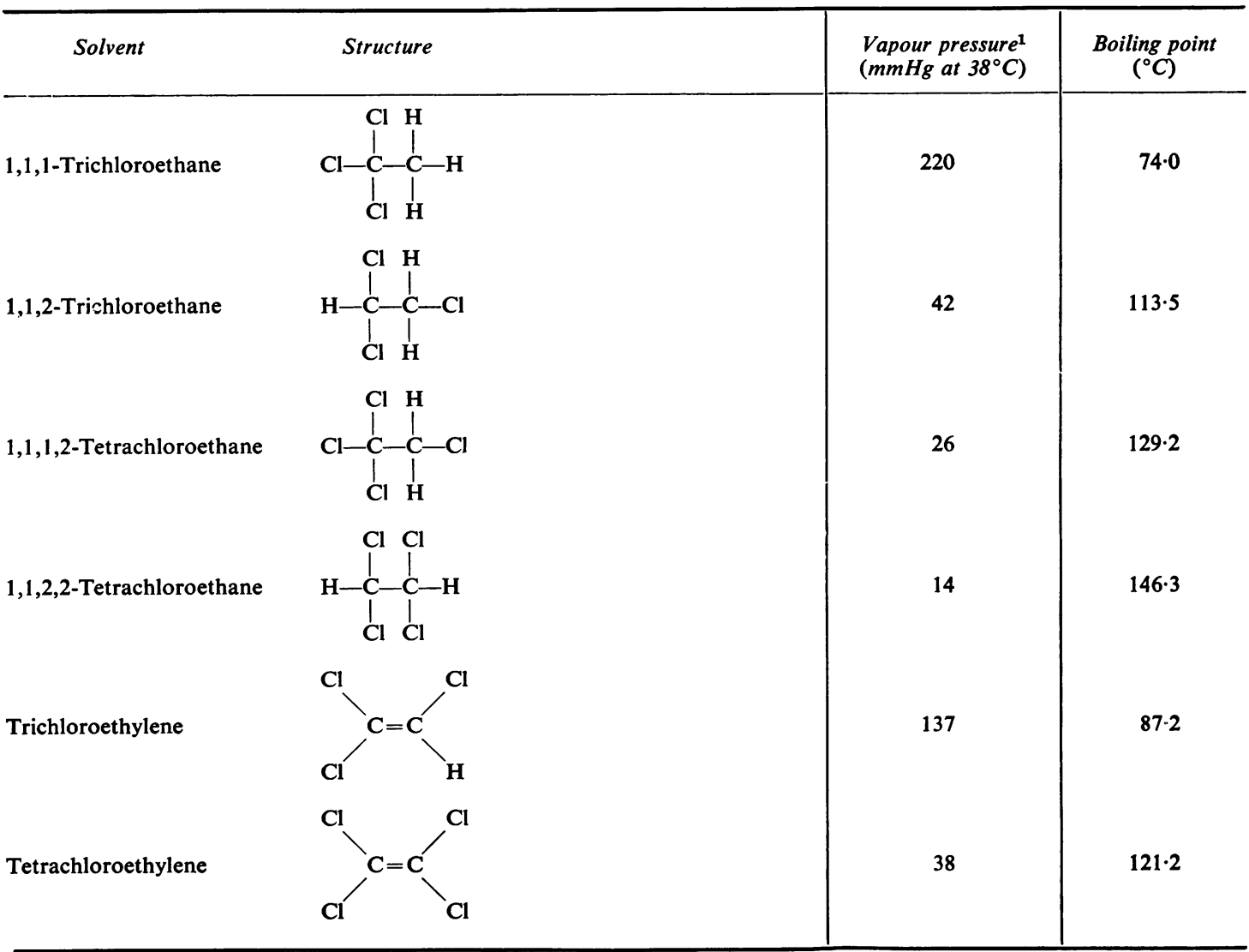

'Estimated from the observed values at adjacent temperatures 
TABLE 2

Excretion of Urinary Metabolites from Rats and Mice Exposed to the VAPOUR OF THE SOLVENTS

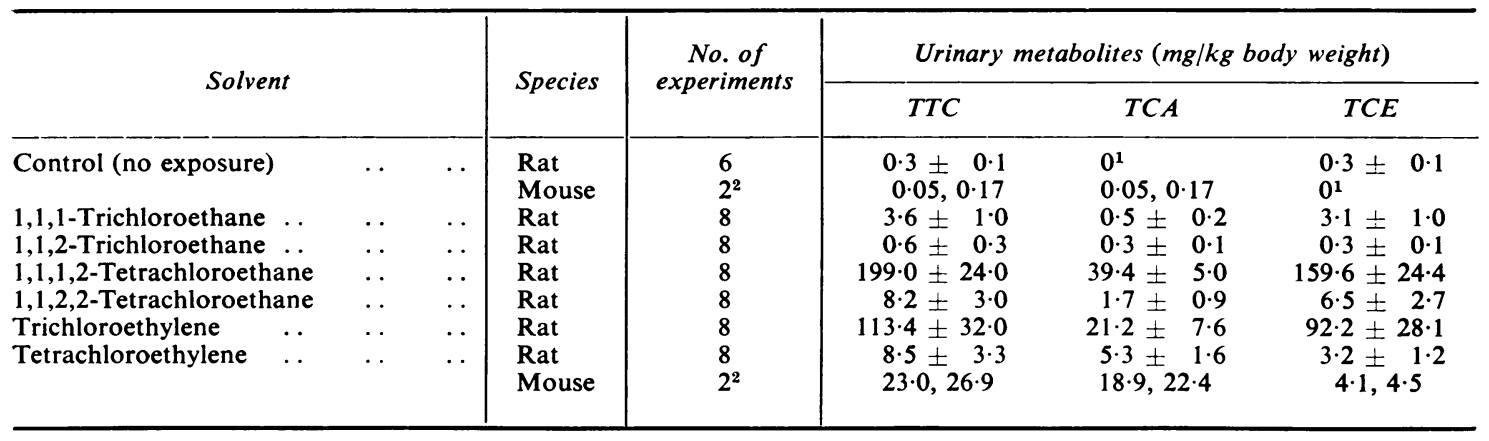

Wistar rats (about $50 \mathrm{~g}, 6$ animals per group) and DD mice (about $25 \mathrm{~g}, 10$ animals per group) were exposed to the vapour of the solvent ( 200 p.p.m.) for 8 hours. Urine samples were collected (separately from faeces) for 48 hours from the beginning of exposure, and analysed with Fujiwara reaction as described under Materials and methods. Values in the table are means \pm S.D.

${ }^{1}$ Amount not measurable

${ }^{2}$ Single results

metabolites, although in much smaller amounts, were found in urine after exposure to tetrachloroethylene. The same was true for human subjects (Table 3) and mice (Table 2) exposed to tetrachloroethylene. It is noteworthy that 1,1,1,2-tetrachloroethane gave rise to large amounts of TCA and TCE whereas its isomer, 1,1,2,2-tetrachloroethane, yielded less than one-twentieth of these amounts. Both isomers of trichloroethane produced very small amounts of metabolites in urine, but 1,1,2-trichloroethane yielded less than its 1,1,1-isomer.

After intraperitoneal injection To eliminate effects of possible differences in the efficiency of pulmonary uptake among the vapours of the solvents tested, equimolar amounts of the solvents $(2.78 \mathrm{mmol} / \mathrm{kg}$ body weight) were injected intraperitoneally into the animals and their urine was collected for the following two 48-hour periods. Results from urine analyses (Table 4) are essentially the same as those obtained from inhalation experiments (Table 2), except that only very little, if any, TCE was excreted in the urine of rats and mice after an injection of tetrachloroethylene. Chloral hydrate, an intermediate in the conversion of trichloroethylene to TCE (Friedman and Cooper, 1960) and TCA (Cooper and Friedman, 1958), gave rise to TCE and TCA. The TCE/TCA ratio was quite close to that observed after the trichloroethylene injection.

\section{Discussion}

Organic solvents taken into the body may be eliminated mainly by excretion into the alveolae and

TABLE 3

Excretion of Metabolites in Urine of Male Workers Exposed to Tetrachloroethylene AND TRICHLOROETHYLENE

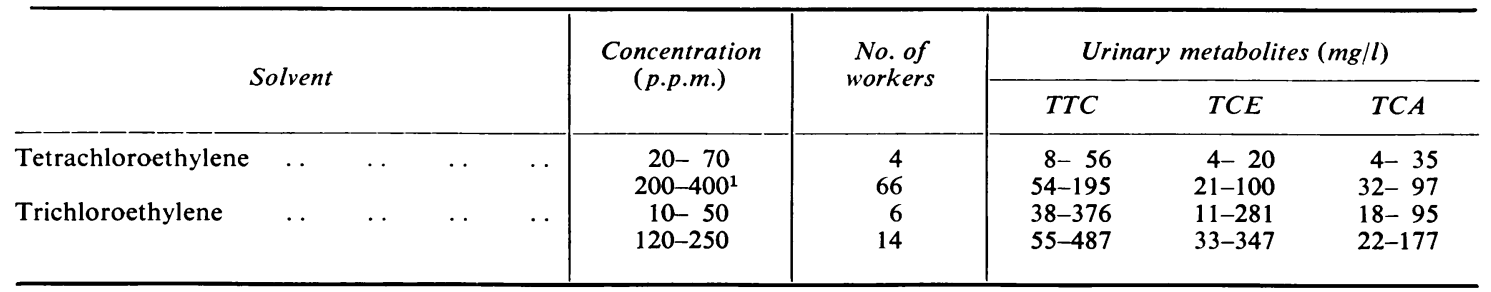

The workers were subject to daily, intermittent exposure. The maximum vapour concentrations recorded are shown, as determined by Kitagawa detection tubes (1960). The ranges of urinary concentrations are shown.

${ }^{1}$ This worker was also in direct skin contact with the liquid. 
TABLE 4

Excretion of Urinary Metabolites from Rats and Mice after Intraperitoneal InJection OF THE SOLVENT

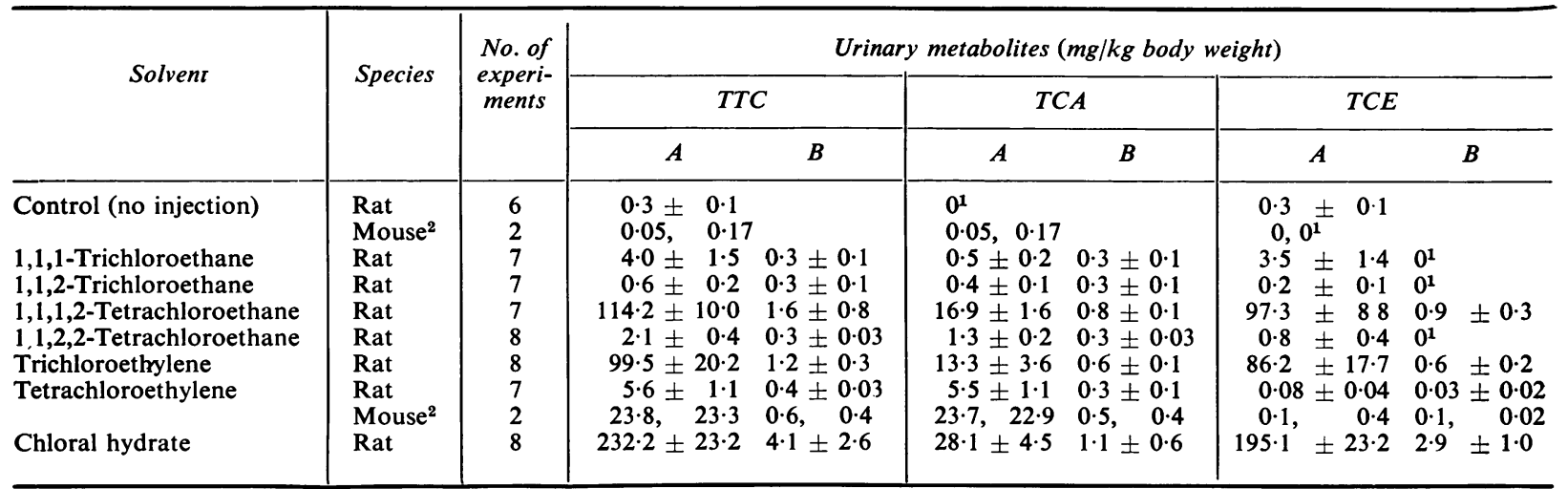

Wistar rats (about $50 \mathrm{~g}, 5$ animals per group) and DD mice (about $25 \mathrm{~g}, 10$ animals per group) were given $2.78 \mathrm{mmol} / \mathrm{kg}$ body weight of the solvents intraperitoneally diluted with or suspended in soy-bean oil to a total volume of $1 \mathrm{ml} / \mathrm{kg}$ body weight. Urine samples collected (separately from faeces) for two successive 48-hour periods were analysed by the Fujiwara reaction as described under Materials and methods. Values in the tables are means \pm S.D. for the first (A) and second (B) 48-hour period after injection.

${ }^{1}$ Amount not measurable. ${ }^{2}$ Single results.

excretion of metabolites through the kidney into urine. Studies by Stewart (1968), Stewart et al. (1969; 1970a, b), and Hake, Waggoner, Robertson, and Rowe (1960) suggest that the proneness of solvents to be excreted into alveolar breath is closely related to such physical properties of the solvents as vapour pressure and boiling point (Table 1). 1,1,1Trichloroethane, with the highest vapour pressure and the lowest boiling point among the solvents studied, was excreted almost completely in the expired air when its ${ }^{14} \mathrm{C}$-labelled preparation was administered intraperitoneally to rats (Hake et al., 1960). The low metabolite levels in urine (Tables 2 and 4) are in accordance with this observation. Trichloroethylene, with a shorter alveolar excretion half-life than tetrachloroethylene (Stewart et al., $1970 \mathrm{a}, \mathrm{b})$, has a higher vapour pressure and a lower boiling point than its tetrachlorinated homologue (Table 1).

Another factor which determines the rate of elimination is the tendency of the compound to undergo biotransformation. The high stability of 1,1,1-trichloroethane (Irish, 1963), coupled with rapid elimination through the lungs, as stated above, may account for the low levels of metabolites of this compound in urine (Tables 2 and 4). The relative levels of TCE and TCA, with TCE considerably the higher, may indicate that the TCA in this case is derived from TCE, which is itself the primary product from the oxidation of 1,1,1-trichloroethane. Although the metabolic pathways of the isomer 1,1,2-trichloroethane are still unknown (Browning, $1965 \mathrm{~b})$, the structure of this compound apparently requires a shift of one chlorine atom from one carbon to the other to form TCA or TCE. Consequently, when this solvent is administered to rats, the levels of TCA and TCE in urine are very low as the occurrence of such a reaction is unlikely. One should also consider the possibility that these estimates by the Fujiwara reaction represent metabolites other than TCA and TCE, as those halogen compounds which have at least two halogen atoms bound to one carbon atom are reactive to the test (Feigl, 1960). The very high yields of TCA and TCE (Tables 2 and 4) from 1,1,1,2-tetrachloroethane can be explained by hydrolytic dehalogenation with the formation of an oxidized hydrocarbon (Williams, 1959). The first step may be the formation of TCE, which then is further oxidized to TCA. As the vapour pressure of 1,1,1,2-tetrachloroethane is lower than that of trichloroethylene or tetrachloroethylene and its boiling point is higher than that of the two chlorinated ethylenes, the rate of elimination of this solvent through the lungs is likely to be very low. Rates of conversion of its 1,1,2,2-tetrachloro isomer to TCA and TCE are much slower, in agreement with the observation that the yields of urinary metabolites from 1,1,2-trichloroethane are lower than those from its $1,1,1$-isomer. It should be noted that the toxicities of 1,1,1-trichloroethane and 1,1,1,2-tetrachloroethane are lower than those of 1,1,2-trichloroethane and 1,1,2,2-tetrachloroethane (Table 5). Accordingly, from the rate of decrease in urinary metabolite concentration, the former two compounds have faster rates of elimination than the latter two (Table 4). 
TABLE 5

LD $_{50}$ OF ChLorinated Ethanes

\begin{tabular}{|c|c|c|c|c|}
\hline Solvent & Species & $\begin{array}{c}\text { Route of } \\
\text { administration }\end{array}$ & $L D_{50}(g / k g)$ & Reference \\
\hline $\begin{array}{l}\text { 1,1,1-Trichloroethane } \\
\text { 1,1,2-Trichloroethane } \\
\text { 1,1,1,2-Tetrachloroethane } \\
1,1,2,2 \text {-Tetrachloroethane }\end{array}$ & $\begin{array}{l}\text { Rat } \\
\text { Mouse } \\
\text { Rat } \\
\text { Mouse } \\
\text { Mouse }\end{array}$ & $\begin{array}{l}\text { Oral } \\
\text { Intraperitoneal } \\
\text { Oral } \\
\text { Intraperitoneal } \\
\text { Intraperitoneal }\end{array}$ & $\begin{array}{l}10 \cdot 3 \text { to } 12 \cdot 3 \\
2 \cdot 568 \\
0 \cdot 1 \text { to } 0 \cdot 2 \\
1.275 \\
0.821\end{array}$ & $\begin{array}{l}\text { Torkelson et al. (1958) } \\
\text { Takeuchi (1966) } \\
\text { Irish (1963) } \\
\text { Takeuchi (1966) } \\
\text { Takeuchi (1966) }\end{array}$ \\
\hline
\end{tabular}

Metabolism of the chlorinated ethylenes is entirely different from that of ethane derivatives in that the first oxidation occurs at the double bond between two carbon atoms with the formation of an epoxide (Byington and Leibman, 1965; Yllner, 1961), which further rearranges to aldehyde or acid chloride:<smiles>O=CC(Cl)(Cl)Cl</smiles><smiles>CC(Cl)(Cl)C(O)N(C(Cl)(Cl)Cl)C(Cl)(Cl)Cl</smiles><smiles>O=C(Cl)C(Cl)(Cl)C(Cl)(Cl)Cl</smiles>

Sjöberg (1952) demonstrated clearly that trichloroethylene is more readily oxidized than tetrachloroethylene. For example, when brought into contact with heated iron, 3, 5, 19, and $14 \mathrm{mg}$ of phosgene were formed per gramme of trichloroethylene at $350,400,450$, and $500^{\circ} \mathrm{C}$, respectively, while only $0.4,1,2$, and $3 \mathrm{mg}$ of phosgene were formed per gramme of tetrachloroethylene at the corresponding temperatures. As $1 \mathrm{~mol}$ of phosgene may be generated from $1 \mathrm{~mol}$ of trichloroethylene or $0.5 \mathrm{~mol}$ of tetrachloroethylene, trichloroethylene is about 10 times as susceptible to oxidation as tetrachloroethylene. In practical use as degreasing agents, it is well known that the former is less stable than the latter (McGovern, 1943). Trichloroethylene epoxide also appears to be more reactive than tetrachloroethylene epoxide. Trials were unsuccessful in isolating trichloroethylene oxide due to its instability (McKinney, Uhing, White, and Picken, 1955), and Byington and Leibman (1965) obtained chloral hydrate rather than trichloroethylene epoxide as the first stable intermediate in their in vitro experiment on trichloroethylene oxidation, while tetrachloroethylene oxide was isolated by vacuum-distillation (Frankel, Johnson, and Pitt, 1957). These chemical properties may explain why the quantities of urinary metabolites were greater from trichloroethylene than from tetrachloroethylene (Tables 2 and 4). As to tetrachloroethylene metabolism, Yllner (1961) did not detect TCE in the urine of mice exposed to ${ }^{14} \mathrm{C}$-tetrachloroethylene, while we observed that the optical density after the Fujiwara reaction increased when the urine of rats, mice or human subjects exposed to tetrachloroethylene vapour was treated with the oxidant prior to the colour-developing reaction (Tables 2 and 3 ). The reason has not yet been extensively studied. The discrepancy could, however, be attributed to differences in the duration and intensity of exposure, because after intraperitoneal injection very little TCE appeared in the urine (Table 4).

The authors are grateful to Professor M. Nishio for his interest in this study. Thanks are also due to Mary O'Halloran for reviewing the manuscript. This work was supported in part by a grant from the Fujiwara Memorial Fund.

\section{References}

Browning, E. (1965a). Toxicity and Metabolism of Industrial Solvents, pp. 189-212. Elsevier, Amsterdam and London.

- (1965b). Toxicity and Metabolism of Industrial Solvents, pp. 258-260. Elsevier, Amsterdam and London.

Byington, K. H., and Leibman, K. C. (1965). Metabolism of trichloroethylene in liver microsomes. II. Identification of the reaction product as chloral hydrate. Molec. Pharmacol., 1, 247-254.

Cooper, J. R., and Friedman, P. J. (1958). The enzymic oxidation of chloral hydrate to trichloroacetic acid. Biochem. Pharmacol., 1, 76-82.

Feigl, F. (1960). Spot Tests in Organic Analysis, 6th English ed., p. 327. Elsevier, Amsterdam and London.

Frankel, D. M., Johnson, C. E., and Pitt, H. M. (1957). Preparation and properties of tetrachloroethylene oxide. J. org. Chem., 22, 1119-1120.

Friedman, P. J., and Cooper, J. R. (1960). The role of alcohol dehydrogenase in the metabolism of chloral hydrate. J. Pharmacol. exp. Ther., 129, 373-376.

Hake, C. L., Waggoner, T. B., Robertson, D. N., and Rowe, V. K. (1960). The metabolism of 1,1,1-trichloroethane by the rat. Arch. environm. Hlth, 1, 101-105.

Irish, D. D. (1963). Aliphatic halogenated hydrocarbons. In Industrial Hygiene and Toxicology, 2nd ed., Vol. 2, edited by F. A. Patty p. 1291. Interscience, New York and London. 
Kitagawa, T. (1960). The rapid measurement of toxic gases and vapour. Proc. 13th int. Congr. occup. Hlth, pp. 506572. New York.

McGovern, E. W. (1943). Chlorohydrocarbon solvents. Industr. Eng. Chem., 35, 1230-1239.

McKinney, L. L., Uhing, E. H., White, J. L.. and Picken, J. C., Jr. (1955). Vegetable oil extraction. Autoxidation products of trichloroethylene. J. agric. Food Chem., 3, 413-419.

Sjöberg, B. (1952). Thermal decomposition of chlorinated hydrocarbons. Svensk. kem.-T., 64, 63-79.

Stewart, R. D. (1968). Toxicology of 1,1,1-trichloroethane. Ann. occup. Hyg., 11, 71-79.

_- Baretta, E. D., and Dodd, H. C. (1970a). Experimental human exposure to tetrachloroethylene. Arch. environm. Hlth, 20, 224-229.

, Dodd, H. C., Gay, H. H., and Erley, D. S. (1970b) Experimental human exposure to trichloroethylene. Arch. environm. Hlth, 20, 64-71.

—_, Gay, H. H., Schaffer, A. W., Erley, D. S., and Rowe,
V. K. (1969). Experimental human exposure to methyl chloroform vapor. Arch. environm. Hlth, 19, 467-472.

Takeuchi, Y. (1966). Experimental studies on the toxicity of 1,1,1,2-tetrachloroethane compared with 1,1,2,2tetrachloroethane and 1,1,1-trichloroethane. Jap. J. industr. Hlth, 8, 371-374.

Tanaka, S., and Ikeda, M. (1968). A method for determination of trichloroethanol and trichloroacetic acid in urine. Brit. J. industr. Med., 25, 214-219.

Torkelson, T. R., Oyen, F., McCollister, D. D., and Rowe, V. K. (1958). Toxicity of 1,1,1-trichloroethane as determined on laboratory animals and human subjects. Amer. industr. Hyg. Ass. J., 19, 353-362.

Williams, R. T. (1959). Detoxication Mechanisms, 2nd ed. p. 25. Chapman and Hall, London.

Yllner, S. (1961). Urinary metabolites of ${ }^{14} \mathrm{C}$-tetrachloroethylene in mice. Nature (Lond.), 191, 820.

Received for publication May 11, 1971

\section{The October (1971) Issue}

Some aspects of the early evolution of the Appointed Factory Doctor Service JAMES A. SMILEY

Decompression sickness in caisson workers SAmir H. El Ghawabi, Mohamed B. MANSOUR, Fatma L. Youssef, Mohamed H. El Ghawabi, and Mohamed M. Abd El Latif

Nutritional and environmental studies on an ocean-going oil tanker. 3. Energy balances and physique T. P. EDDY, ANNE L. STOCK, AND ERICA F. WheELER

Nutritional and environmental studies on an ocean-going oil tanker. 4. The diet of seamen T. P. EDDY, ERICA F. WheEler AND ANNe L. STOCK

Studies on the diagnosis and pathogenesis of Raynaud's phenomenon of occupational origin AKIRA OKADA, Takamasa Yamashita, Chieko Nagano, Toshiko Ikeda, Akira Yachi, and Shigeru Shibata

Bronchitis in men employed in the coke industry D. D. WALkeR, R. M. ARChiBALD, AND M. D. ATTFIELD

A comparative study of respiratory function in female non-smoking cotton and jute workers F. VALIĆ AND EUGENIJA ŽUŠKIN

Effect of extremes of temperature and humidity on the goblet cell count in the rat airway epithelium Rosemary Jones, ANNA M. BAETJer, AND LyNNe Reid

Psychological picture of manifest and latent carbon disulphide poisoning HeLENA HÄNNINEN

Excretion of hippuric acid and $m$ - or $p$-methylhippuric acid in the urine of persons exposed to vapours of toluene and $m$ - or $p$-xylene in an exposure chamber and in workshops, with specific reference to repeated exposures Masana Ogata, Yoshiko Takatsuka, and Katsumaro Tomokuni

Excretion of organic chlorine compounds in the urine of persons exposed to vapours of trichloroethylene and tetrachloroethylene Masana Ogata, Yoshiko Takatsuka, and Katsumaro Tomokuni

Determination of lead in capillary blood using a paper punched disc atomic absorption technique A. A. Cernik AND M. H. P. SAYers

Nail damage in spray operators exposed to paraquat C. E. D. HeArN AND W. KeIR

Book reviews

A number of copies are still available and may be obtained from the Publishing Manager. British Medical Association, Tavistock Square, London WC1H 9JR price $£ 1.25$ ( $£ 1.5$ in countries overseas; U.S.A. $\$ 3 \cdot 60)$. 